\title{
Use of social networking site by library science students: A comparative study of maharishi dayanand university, rohtak and kurukshetra university kurukshetra
}

\author{
Lalita Honhaga
}

Master scholar, Women's College, Jamshedpur, Kolhan University, Chaibasa, Jharkhand, India

*Corresponding Author: Lalita Honhaga

Email: lalitahonhaga8@gmail.com

\begin{abstract}
ICT brings change in information seeking habit of students. Books are the main sources of information but after the introduction of ICT patrons are collecting information from internet so that they do not required to visit the library. Today's youth is more into the social networking. They spend more time on SNS. Initially SNS are use just to socialize with family and friends. But innovation also occur in use of social media. Corporates, business education institutes are started using SNS for marketing their sources. Similarly users started using SNS for different purpose like to study, group discussion, exchanging notes etc. In current research comparative study of use of SNS by two university's library science students is studied. Data have been collected with the help of structured questionnaire and after analyzing the data it is found that users are using SNS for exchanging idea with friends but some user awareness program is also required for better utilization of the same.
\end{abstract}

Keyword: Web-base Services, ICT, Facebook.

\section{Introduction}

Advancement in information and communication technology decreases the geographical distance between people. To exchange ideas, talk with friends and relatives nowadays it is not compulsory to meet them personally. Use of ICT helps us to talk with them through telephone, mobile device or through different social networking sites. The Question arises in our mind that what exactly social networking sites are? SNSs are defined by Body and Ellison (2008:11) as "web-based services that allow individuals to (1) construct a public or semi-public profile within a bounded system, (2) articulate a list of other users with whom they share a connection, and (3) view and traverse their list of connections and those made by others within the system"

Facebook, Twitter, YouTube, WhatsApp, Instagram etc., are the example of social networking sites. Not only an individual but also many brands, companies, organizations, public institutions uses social networking sites for communicating their sources and services to the mass. Having public Facebook page, a Twitter account, YouTube channel is common nowadays.

Libraries are now legging behind. Library and information word is always adapting new challenges. Libraries launch website in 1990, in 2000 it started providing chat and e-mail digital reference services. Today many libraries are having their website as well as Facebook page, blogs etc. The libraries which are disseminating their information sources and services by displaying notice on notice board are using these SNS services for the same. More youth are on social media, so it attracts their attention towards libraries.

The current research aims to identify awareness of SNS among library science students, purpose of using SNS. It also identifies which social networking site users are using and what is their satisfaction level.

\section{Literature review}

Adebayo (2015) in his paper, "The awareness and use of social networking sites by the students of library and information science in Federal Polytechnic, Offa. Nigeia" said that from analysing the data it was found that more users are using SNS. 93.8\% respondents are using the SNSs to connect themselves with their friends for chat, $75.9 \%$ access reported by SNSs for academic work/research work and $49.1 \%$. for leisure/entertainment.

Abdelraheem (2013) in his paper found that Facebook, YouTube and Flicker SNSs are the most popular among the respondents in Sultan Qaboos University. They are using social networking sites for social matters more than for the academic purposes. They are using smart mobile phones for accessing SNSs in comparison to the normal mobiles phones. Further, the study revealed that more than fifty percent of the respondents are spending two hours or more than two hours per day on using SNS.

\section{Objective of the study}

The paper has following objectives

1. To identify user awareness about social networking sites

2. To identify purpose of using SNSs

3. To identify ideal social networking site by the LIS students;

4. To ascertain the effects of SNSs on LIS students

5. To identify the problem faced by LIS students

\section{Research Methodology}


The main of the study is to identify the use of SNSs by library and information science students of Kurukshetra University, Kurukshetra and Maharishi Dayanand University, Rohtak.

Questionnaire method was adopted for conducting the survey to get the opinion of the respondents. Data have been collected from 138 students from both the university. The data have been identified using MS Excel. Simple percentage method have been used for analysis.

\section{Data analysis}

The questionnaire have been distributed among Maharshi Dayanand University, Rohtak and Kurukshetra University, Kurukshetra. Total 150 questionnaire have been distributed among 144 is received back and 130 questionnaire were found valid for the analysis. The main purpose of the study is to find our user awareness of using SNS and their views on using different SNSs.

Table 1: Programmes (In LIS) and gender wise distribution

\begin{tabular}{|c|c|c|c|c|c|c|c|}
\hline University & Gender & BLIS (\%) & MLIS (\%) & M.Phil. (\%) & Ph.D. (\%) & Total (\%) & Grand Total (\%) \\
\hline \multirow{3}{*}{ MDU } & Male & $14(23.33)$ & $12(20)$ & - & $4(6.66)$ & $30(50)$ & 60 \\
\cline { 2 - 7 } & Female & $10(15.62)$ & $17(26.56)$ & - & $3(4.69)$ & $30(46.87)$ & $(46.15)$ \\
\hline \multirow{2}{*}{ KUK } & Male & $8(10.81)$ & $5(6.77)$ & $13(17.56)$ & $7(9.45)$ & $33(44.59)$ & 70 \\
\cline { 2 - 7 } & Female & $10(14.28)$ & $11(15.71)$ & $13(17.57)$ & $3(4.06)$ & $37(55.40)$ & $(53.62)$ \\
\hline
\end{tabular}

Table 1 shows that majority of the respondents i.e. 74 (53.62\%) are from KUK consisting of $41(55.41 \%)$ male respondents and $33(44.59 \%)$ female respondents whereas 60 (46.15\%) respondents are from MDU consisting of $30(50 \%)$ male and $30(46.87 \%)$ female respondents

Table 2: Usage of internet

\begin{tabular}{|c|c|c|c|}
\hline Course & MDU (\%) & KUK (\%) & Total (\%) \\
\hline BLIS & $24(37.5)$ & $20(27.03)$ & $44(31.88)$ \\
\hline MLIS & $\mathbf{3 3 ( 5 1 . 5 6 )}$ & $18(24.32)$ & $\mathbf{5 1}(\mathbf{3 6 . 9 6 )}$ \\
\hline M.PHIL. & - & $25(34.24)$ & $25(19.23)$ \\
\hline Ph.D. & & $10(13.51)$ & $10(7.69)$ \\
\hline Total & 57 & 73 & 130 \\
\hline
\end{tabular}

Table 2 shows that $33(51.56 \%)$ users in MDU are from MLIS and 24 (37.5\%) BLIS students respondents. Whereas in KUK, majority of the Internet user i.e. 25 (34.24\%) are from M.Phil. followed by 20 (27.03\%) and, 18 (24.32\%), who are from BLIS and MLIS respectively

Table 3: Usage of social networking sites (SNSs) by the respondents

\begin{tabular}{|c|c|c|c|c|c|}
\hline \multirow{2}{*}{ Respondent } & \multicolumn{2}{|c|}{ MDU (\%) } & \multicolumn{2}{c|}{ KUK (\%) } & Total (\%) \\
\cline { 2 - 6 } & Yes & No & Yes & No & \\
\hline BLIS & $20(31.25)$ & - & $20(27.03)$ & - & $40(30.76)$ \\
\hline MLIS & $33(51.56)$ & - & $14(18.91)$ & - & $47(36.15)$ \\
\hline M.Phil. & - & - & $26(35.13)$ & - & $26(18.84)$ \\
\hline Ph.D. & $7(10.94)$ & - & $10(13.51)$ & - & $17(12.31)$ \\
\hline Total & 60 & - & 70 & - & 130 \\
\hline
\end{tabular}

Table 3 shows that all the students of both the universities are aware of social networking sites and its utility.

Table 4: Purpose of using (SNSs) by the respondents

\begin{tabular}{|c|c|c|c|c|c|c|c|c|c|}
\hline \multirow{2}{*}{ Purpose } & \multicolumn{4}{|c|}{ MDU } & \multicolumn{5}{c|}{ KUK } \\
\cline { 2 - 11 } & BLIS & MLIS & Ph.D. & Total\% & BLIS & MLIS & M.Phil. & Ph.D. & Total\% \\
\hline Education & 24 & 25 & 6 & $55(91.67)$ & 14 & 17 & 23 & 9 & $63(90)$ \\
\hline Entertainment & 8 & 14 & 5 & $27(45)$ & 12 & 13 & 18 & 8 & $51(72.85)$ \\
\hline Research work & - & 7 & 6 & $13(21.67)$ & 3 & 5 & 20 & 9 & $37(52.85)$ \\
\hline Socializing & 6 & 11 & 4 & $21(35)$ & 9 & 3 & 5 & 6 & $23(32.85)$ \\
\hline
\end{tabular}

Table 4 depicts that majority of the respondents i.e. 55 (91.67\%) of MDU are using SNSs for the purpose of education followed by the 27 (45\%), 21 (35\%), and 13 (21.67\%) respondents who are using SNSs for the purpose of entertainment, socializing and research work respectively by purpose. Majority of the respondents i.e. 63 (90\%) in KUK are using SNSs for 
education followed by $51(72.85 \%)$ respondents who are using SNSs for entertainment, 37 (52.85\%) respondents are using it for research work and $23(32.85 \%)$ are using it for the purpose of socializing with others.

Table 5: Most preferred SNSs by the respondents

\begin{tabular}{|c|c|c|c|c|c|c|c|c|c|}
\hline \multirow[b]{2}{*}{ SNSs } & \multicolumn{3}{|c|}{ MDU } & \multirow[b]{2}{*}{ Total\% } & \multicolumn{4}{|c|}{ KUK } & \multirow[b]{2}{*}{ Total\% } \\
\hline & BLIS & MLIS & Ph.D. & & BLIS & MLIS & M.Phil. & Ph.D. & \\
\hline Facebook & 10 & 28 & 6 & $44(73.33)$ & 15 & 11 & 24 & 8 & $58(82.86)$ \\
\hline Twitter & 6 & 4 & 4 & $14(23.33)$ & 3 & 3 & 10 & 5 & $21(30)$ \\
\hline Lislinks & 1 & 10 & 5 & $16(26.67)$ & 3 & 3 & 16 & 7 & $29(41.43)$ \\
\hline Instagram & 1 & 4 & - & $5(8.33)$ & 4 & 5 & 5 & 3 & $17(24.28)$ \\
\hline Flicker & 2 & 3 & - & $5(8.33)$ & 1 & - & 5 & 2 & $8(11.43)$ \\
\hline Linkedin & 1 & 6 & 4 & $11(18.33)$ & 2 & 2 & 10 & 6 & $20(28.57)$ \\
\hline YouTube & 17 & 26 & 6 & $49(81.67)$ & 17 & 11 & 23 & 10 & 61(87.14) \\
\hline Wikipedia & 17 & 12 & 7 & $36(60)$ & 7 & 14 & 22 & 8 & $51(72.85)$ \\
\hline
\end{tabular}

Table 5 represents the most preferred SNSs among MDU and KUK respondents. Majority of the respondents i.e. 49 $(81.67 \%)$ from MDU and $61(87.14 \%)$ respondents from KUK prefer to use YouTube for various educational and entertainment followed by Facebook which is the second most preferred SNS as replied by $44(73.33 \%)$ respondents of MDU and $58(82.86 \%)$ respondents of KUK. Wikipedia is the third most preferred SNS as replied by $36(60 \%)$ respondents of MDU and $51(72.85 \%)$ respondents of KUK. While Flicker, Myspace are the least used SNSs as replied by the respondents of MDU and KUK.

Table 6: Reasons for using SNSs

\begin{tabular}{|c|c|c|c|c|c|c|c|c|c|c|}
\hline \multirow[b]{2}{*}{ SNSs help } & \multicolumn{3}{|c|}{ MDU } & & \multicolumn{4}{|c|}{ KUK } & & \multirow[t]{2}{*}{ Total\% } \\
\hline & BLIS & MLIS & Ph.D. & Total \% & BLIS & MLIS & M.Phil & Ph.D & Total \% & \\
\hline $\begin{array}{c}\text { For better } \\
\text { exchange of ideas }\end{array}$ & 18 & 19 & 3 & $\begin{array}{c}40 \\
(66.67)\end{array}$ & 11 & 14 & 15 & 6 & $\begin{array}{c}46 \\
(65.71)\end{array}$ & $\begin{array}{c}86 \\
(66.15)\end{array}$ \\
\hline Save time & 4 & 12 & 2 & $\begin{array}{c}18 \\
(30)\end{array}$ & 6 & 3 & 14 & 5 & $\begin{array}{c}28 \\
(40)\end{array}$ & $\begin{array}{c}46 \\
(35.38)\end{array}$ \\
\hline Keep updated & 8 & 14 & 5 & $\begin{array}{c}27 \\
(45) \\
\end{array}$ & 9 & 13 & 22 & 9 & $\begin{array}{c}53 \\
(75.71) \\
\end{array}$ & $\begin{array}{c}80 \\
(61.53) \\
\end{array}$ \\
\hline Any other specify & - & - & - & - & - & 1 & - & - & $\begin{array}{c}1 \\
(1.43)\end{array}$ & $\begin{array}{c}1 \\
(0.77)\end{array}$ \\
\hline
\end{tabular}

Table 6 shows that majority of the respondents i.e. 40 (66.67\%) in MDU use SNSs as it helps in the better exchange of ideas whereas, in KUK majority of the respondents i.e. 53 (75.71\%) use SNSs as it helps in keeping them updated.

Table 7: Problem FACED while using SNSs

\begin{tabular}{|c|c|c|c|c|c|c|c|c|c|c|}
\hline \multirow{2}{*}{ Problem faced } & \multicolumn{3}{|c|}{ MDU } & \multirow{2}{*}{$\begin{array}{l}\text { Total } \\
(\%)\end{array}$} & \multicolumn{4}{|c|}{ KUK } & \multirow{2}{*}{$\begin{array}{c}\text { Total } \\
(\%)\end{array}$} & \multirow{2}{*}{$\begin{array}{c}\text { Grand } \\
\text { Total }(\%)\end{array}$} \\
\hline & BLIS & MLIS & Ph.D. & & BLIS & MLIS & M.Phil. & Ph.D. & & \\
\hline $\begin{array}{c}\text { Lack of technical } \\
\text { awareness }\end{array}$ & 5 & 11 & 2 & $\begin{array}{c}18 \\
(25)\end{array}$ & 5 & 8 & 10 & 2 & $\begin{array}{c}25 \\
(35.71)\end{array}$ & $\begin{array}{c}43 \\
(33.07)\end{array}$ \\
\hline Not user friendly & 2 & 6 & 2 & $\begin{array}{c}10 \\
(16.67)\end{array}$ & 1 & - & - & 1 & $\begin{array}{c}2 \\
(2.85)\end{array}$ & $\begin{array}{c}12 \\
(9.23)\end{array}$ \\
\hline $\begin{array}{l}\text { Poor internet } \\
\text { connectivity }\end{array}$ & 11 & 14 & 5 & $\begin{array}{c}30 \\
(\mathbf{5 0}) \\
\end{array}$ & 13 & 10 & 15 & 6 & $\begin{array}{c}44 \\
(62.85) \\
\end{array}$ & $\begin{array}{c}74 \\
(56.92) \\
\end{array}$ \\
\hline No privacy & 6 & 3 & 2 & $\begin{array}{c}11 \\
(18.33)\end{array}$ & 7 & 2 & 3 & 4 & $\begin{array}{c}16 \\
(22.85)\end{array}$ & $\begin{array}{c}27 \\
(20.76)\end{array}$ \\
\hline Lack of security & 11 & 15 & 2 & $\begin{array}{c}28 \\
(46.67)\end{array}$ & 10 & 8 & 9 & 2 & $\begin{array}{c}29 \\
(41.42)\end{array}$ & $\begin{array}{c}57 \\
(43.85) \\
\end{array}$ \\
\hline Lack of time & 7 & 17 & 1 & $\begin{array}{c}25 \\
(41.67)\end{array}$ & 3 & 3 & 9 & 2 & $\begin{array}{c}17 \\
(24.28)\end{array}$ & $\begin{array}{c}42 \\
(32.31)\end{array}$ \\
\hline Any other specify & - & 1 & - & $\begin{array}{c}1 \\
(1.67)\end{array}$ & - & - & - & 2 & $\begin{array}{c}2 \\
(2.85)\end{array}$ & $\begin{array}{c}2 \\
(1.53)\end{array}$ \\
\hline
\end{tabular}


Table 7 represents that the majority of the respondents i.e. 74 (56.92\%) from MDU and KUK expressed "poor Internet connectivity" as the major problem faced while accessing the SNSs followed by 28 (46.67\%) MDU respondents who find lack of technical awareness as the second major problem faced by the students. Whereas in KUK this problem is ranked as the third most faced problem by $25(35.71 \%)$ respondents, lack of security problem which was ranked second by $29(41.42 \%)$ respondents of KUK. Minimum number of MDU and KUK respondents i.e. $10(16.67 \%)$ and $2(2.85 \%)$ feel that SNSs are less user friendly.

\section{Conclusion}

It is concluded in the present study that all the respondents of both the universities are using internet and SNSs. More students use YouTube and Facebook for education purpose. KUK students uses SNS at home whereas MDU students uses it at library. They chat with LIS students and friends. Students uses SNS to exchange ideas and to keep themselves up to date, they also believe that it save their time. At last it is required to conduct awareness program to educate the students regarding the use of the SNSs

\section{References}

1. Ahmed Khan, S., and Bhatti, R. (2012). Application of social media in marketing of library and information services: A case study from Pakistan. Webology, 1(12).

2. Aillerie, K., and McNicol, S. (2016). Are social networking sites information sources? Informational purposes of highschool students in using SNSs. J Libr Inf Sci, 2016;50(1):103114. doi:10.1177/0961000616631612.

3. Ansari, A., and Mehfoozul, H. (2015). Use of Social Networking Sites in Library and Information Centres. New Delhi.

4. Chen, D. Y., Chu, S. K., and Xu, S. (2012). How do libraries use social networking sites to interact with users. Proceedings of the American Society for Information Science and Technology, 49(1), 1-10. doi:10.1002/meet.14504901085.

5. Kaushik, A. Use of Social Networking Sites Tools and Services by LIS Professionals for Libraries: A Survey. DESIDOC J Libr Inf Technol, 2016;36(5), 284-290. doi:10.14429/djlit.36.5.10283.

How to cite this article: Honhaga. L, Use of social networking site by library science students: A comparative study of maharishi dayanand university, rohtak and kurukshetra university kurukshetra, Indian J Libr Sci Inf Techno. 2018;3(2):90-93 